\title{
Lost in Collocation: When Arabic Collocation Dictionaries Lack Collocations
}

\author{
Mohamed Mazen Galal ${ }^{1}$ \\ ${ }^{1}$ English Department, Faculty of Arts, Suez University, Suez, Egypt \\ Correspondence: Mohamed Mazen Galal, English Department, Faculty of Arts, Suez University, Suez, Egypt. \\ E-mail: mazen_galal@yahoo.com
}

\author{
Received: March 27, 2015 Accepted: April 13, 2015 Online Published: May 31, 2015 \\ doi:10.5539/ells.v5n2p18 URL: http://dx.doi.org/10.5539/ells.v5n2p18
}

\begin{abstract}
Arabic has always been in bad need of collocation dictionaries. However, the only two recent English/Arabic \& Arabic/English dictionaries that emerged, Dar El-Ilm's Dictionary of Collocations (DEDC) and Al-Hafiz Arabic Collocations Dictionary (AACD) suffer from serious problems. Although DEDC has a wide range of items covered, it suffers from the serious problem of disregarding the Arabic legacy of collocational equivalents while translating the English terms. English collocation structures, therefore, are translated into free Arabic word combinations. AACD, on the other hand, has the perceived problem of the deficiency in the range of items covered for each entry, ignoring that Arabic, a lexically rich language, can provide a remarkable range of collocational material on different word entries. The two dictionaries would be of greater help for language learners and translation practitioners if those problems were addressed. This paper focuses on those particular weaknesses putting forward alternative suggestions about how to tackle the deficiencies.
\end{abstract}

Keywords: Arabic, Collocations, English-Arabic Dictionaries

\section{Introduction and Theoretical Background}

\subsection{Overview and Organization of the Study}

Due to the importance of collocations in language learning and practice, collocation dictionaries in different languages have come out to help learners overcome difficulties that face them. The English language, in particular, has an enormous wealth of dictionaries that have always been found to be useful and handy for learners of English. Arabic, on the other hand, has had only very few dictionaries that specifically focus on collocations; only recently two dictionaries of collocations have been compiled, namely Dar El-Ilm's Dictionary of Collocations (DEDC) (English-Arabic) (2007) by Dr. Hasan Ghazala and Al-Hafiz Arabic Collocations Dictionary (AACD) (Arabic-English) (2004) by Dr. Al-Tahir A. Hafiz. The effort behind compiling those dictionaries is laudable and they have been welcome new-comers to the arena. However, the two works, though useful and badly needed, suffer from certain weaknesses, particularly as regards rendering English collocation entries into Arabic free combinations, disregarding the existence of ready Arabic collocations that can serve as relatively equivalent to the English ones (the case of DEDC), and in relation to the shortage of the collocation range covered (the case of AACD). This paper mainly explores the problems with the two collocation dictionaries and suggests introducing original Arabic collocational alternatives to maximize their benefits.

This paper is structured as follows. This section is an introduction to the study that includes the definition of collocations and illustrates the differences between collocations and free word combinations. This section also tackles the importance of collocations for language learning and translation, and presents an overview of prominent collocation dictionaries in English as well as some of the Arabic old linguistic works that feature collocation material. Sections 2, 3 and 4 show the significance and problem of the study, the methods used, and the scope within which the study falls. The analysis of the two collocation dictionaries under study is presented in section 5. Section 6 is particularly important since it is the focus of the study displaying the weaknesses of those collocation works and how they may be addressed. The final concluding section restates the results of the analysis, highlights the achievements, and outlines the implications of the study.

\subsection{The Definition of Collocation}

Although some scholars may argue that the linguistic phenomenon of collocation is far from being fully 
understood (Gries, 2013), there has been a general consensus about the meaning of the term 'collocation' in the relevant literature. Firth is the most widely-acclaimed to be the 'father of collocations'. His definition, perhaps the most basic and the oft-quoted definition of collocation, is as simple as: "You shall know a word by the company it keeps" (1957, p. 179). He was the first to establish the expression collocation as a technical linguistic term: "I propose to bring forward as a technical term, meaning by "collocation"” (p, 194). To illustrate what he meant by collocation, he gave the example of the word ass which has to collocate naturally within limited contexts: "You silly ; don't be such an " (p, 196). He states that among many possibilities, 'ass' can collocate with a limited set of adjectives: silly, obstinate, stupid, awful. He also elucidates his case by the example of the word night which naturally collocates with dark, and dark, in turn, naturally collocates with night (p. 196). Firth asserts that collocation works at the syntagmatic level and is not necessarily conceptual or related to the meaning of words. This syntagmatic relation has been asserted also by Sinclair (1991) who sees collocation as "the occurrence of two or more words within a short space of each other in a text" (1991, p. 170). Stubbs also agrees that collocation involves 'The habitual co-occurrence of words' (1995, p. 245).

The same concept of collocation as being a habitual association between words that tend to occur in the same environment is asserted by Leech (1974) and by Kjellmer (1987). Kjellmer (1987, p.133) defines a collocation as 'a sequence of words that occurs more than once in identical form....and is grammatically well structured'. In the same vein, Clear (1993, p. 277) reiterates the concept of collocation involving 'a recurrent co-occurrence of words'. The same assertion has been made by Stubbs (1995), Moon (1998), and Aitchison (2003). O'dell and McCarthy $(2008$, p. 6) exemplify this by illustrating the collocational domains of the two lexical items fast and quick. The adjectives fast and quick, despite their semantic proximity, have two separate but almost fixed domains of use. Native speakers readily know that fast can be used with cars, food; and quick with glance and meal so that a *fast glance and a *fast meal are totally unnatural. This kind of relative collocational fixedness creates a sense of naturalness to native speakers. It is this naturalness experienced by natives that makes it incumbent upon non-natives to make a special effort to learn collocations.

Since collocations form a part of what is known as formulaic language, it is necessary to identify the distinctions between collocations and free word combinations. The following sub-section deals with this discrimination.

\subsection{Collocations and Free Combinations}

Free combinations, as their name suggests, are combinations of words that occur freely without specific restrictions. They allow free substitution, in the sense that there are no restrictions in terms of grammar or semantics on the words that come together. Reaching the total meaning of those elements is easily done by putting together the included elements. Free combinations are represented by instances such as white car, white plate, white shirt, white blouse, white ship, etc. (Maurer-Stroh, 2004, p. 29).

Collocations, on the other hand, are combinations that frequently co-occur yet the combination of the constituents inside them is not free. The elements within a collocation are arbitrarily co-selected and semantically transparent. By arbitrariness it is meant that among the semantically possible elements that word can select only some combinations occur rather than others. Based on Maurer-Stroh, (2004, p. 26), the word (solar) eclipse, for example, can possibly take absolute, complete, entire or whole as candidate descriptive adjectives; yet only total eclipse sounds natural and is taken to be an acceptable collocation. Sinclair (2004, p. 29) points out this aspect of collocation patterns by stating that "many of these patterns seem almost purely linguistic ([...], where on semantic grounds the adjectives should be interchangeable, but on collocational grounds they are not". Bo Svensén (1993, p. 99) illustrates this point by explaining why it is correct to say to make a trip, but incorrect to say * make a walk. His explanation is that collocations are determined by usage, not by semantic conditions. Allerton (1984, p. 28) highlights this rather arbitrary nature of collocation selection: "Language simply seems to dictate, for no good semantic reasons, that such-and-such a combination does, or does not, occur. The restriction is, thus, an arbitrary one."

Based on Aisenstadt (1979), Benson (1985), Heliel (1990), Bahns (1996), Maurer-Stroh (2004), arbitrariness of collocational co-selection is redefined in terms of 'restricted commutability', which results from semantic tailoring, and frequency of co-occurrence. Restricted commutability is exemplified by the collocation heavy rain, where rain can be replaced by only restricted set of alternatives: heavy frost / traffic / drinking / smoking (examples from Maurer-Stroh, 2004, p. 29). Heavy in this collocation, also, can be exclusively replaced by a limited set of alternatives: pouring/ lashing / driving /torrential rain. For free word combinations such as heavy bag, as Maurer-Stroh explains, both elements can be replaced by others, e.g. light /brown / plastic /diplomatic / medical bag and heavy suitcase/ basket / trunk / stone/ boulder / box / umbrella.

As for the frequency of occurrence, which is typically one of the characteristics of collocations, collocational 
components occur more frequently than free word combinations. White car is a free combination since you can swab the adjective and the noun freely with various alternatives with no significant influence on naturalness of the expression. Also for white car, white does not collocate (co-occur) with car in a restrictive manner so that it is possible to have white car, white plate, white shirt, white blouse, white ship, etc (Maurer-Stroh, 2004, p. 29). For the case of the collocation key issue, for example, the adjective key occurs more often than not with the noun issue almost restrictively.

There are good reasons, then, to distinguish collocations from free combinations. Since we have defined collocations and have shown that they are different from free combinations, the coming sub-section will show the importance of collocations for language learning and translation.

\subsection{Collocations in Language Learning and Translation}

Studies have shown that collocations cause formidable problems for language learners. One of the early pioneers of English language teaching, Harold E. Palmer, pinpointed collocations as one of the tremendous difficulties that face learners of this language indicating that "vague and undefined obstacle to progress in the learning of English consists for the most part in the existence of so many odd comings-together-of-words." (Palmer, 1933, p. 13 quoted in Maurer-Stroh, 2004, p. 4). This classic opinion still holds up to the present. Wray (2002, p. ix) asserts that formulaic language learning is "...the final difficult hurdle for the proficient learner who wants to sound truly nativelike".

Learning collocations has proven to be crucial for the process of language learning, spoken and written modes. For speaking, using collocation gives a natural flavor to one's speech. Smoking is strictly forbidden, for example, as Maurer-Stroh (2004) explains, is more natural than smoking is strongly forbidden. Moreover, As Maurer-Stroh maintains (2004) collocation offers alternative ways of saying something. Instead of repeating it was very cold and very dark, we can say it was bitterly cold and pitch dark. Use of collocation also enhances writing style through diversification by offering alternatives to writers. For instance, instead of repeating poverty causes crime, you can ramify into other equal expressions such as poverty breeds crime; instead of saying a big meal you can variegate into something like a substantial meal (Maurer-Stroh, 2004). Wardell (1991) focuses on the importance of training students to use collocations. He reiterates that since collocation is a real problem for second language learners training non-natives to use collocations adequately and purposefully has to be a priority in language learning.

Arab learners of English are not immune from the collocational problems that learners of other languages have gone through. AbuSsaydeh (1991, p. 70) asserts that collocations present a formidable impediment for Arab language learners:

the claim that the major problems the learner frequently encounters are predominantly lexical rather than grammatical is probably nowhere apparent and valid than in the area of collocation; the generation of collocably compatible strings in a foreign language has always plagued even advanced learners.

Farghal and Obeidat (1995), using a gap-fill task, reported similar results on testing the knowledge of 22 English collocations amongst L1 Arabic learners majoring in English at a Saudi university. On the gap-fill task, learners achieved only $18.3 \%$ correct responses, and on the translation task, they did even worse, $5.5 \%$. In a study conducted on a number of Arab students majoring in English, Hussein (1997) has proved the incompetence of those students' production of English collocations; correctness rate stood only at 39\%. Transfer ranked first as a possible reason for errors. It has also been reported that Kuwaiti students suffer from lexical collocation problems based mainly on mother tongue interference and other factors (Alotaibi, 2015). Collocations are also a problem for foreign learners of Arabic even at advanced levels (Hafiz, 2004, p. 1).

Another area of linguistic inquiry in which we find that collocations constitute a real challenge is that of translation. We will particularly focus on English $<>$ Arabic translation problems.

Since every language has its own method of handling collocational units, it is expected that collocations will raise lots of problems in translation. Semantic/lexical congruence is one of those problems. Sometimes it is possible to find congruence between languages in terms of collocation correspondence. As Abu-Ssaydeh (1991, p. 2) explains, ذرف الدمع darafa l-dam3 in Arabic, for example, fully matches he sheds tears in English. However, divergence in collocation is also possible and is even often the case. The following is an illustrative set of divergent collocations in English and Arabic (quoted in William Trotter, 2000, based on multiple sources): 


\begin{tabular}{|c|c|}
\hline $\begin{array}{l}\text { horse's hoof } \\
\text { cow's hoof } \\
\text { camel's hoof }\end{array}$ & 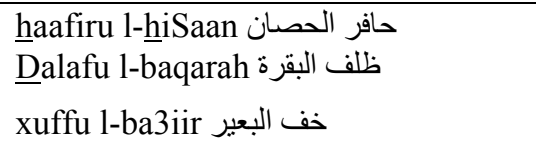 \\
\hline $\begin{array}{l}\text { tall buildings } \\
\text { tall mountains } \\
\text { tall trees }\end{array}$ & 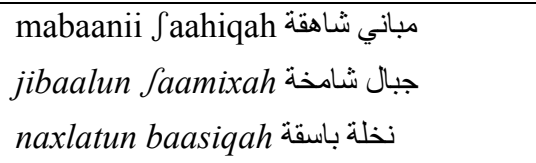 \\
\hline $\begin{array}{l}\text { great distance } \\
\text { great speed } \\
\text { great wealth } \\
\text { great hopes }\end{array}$ & 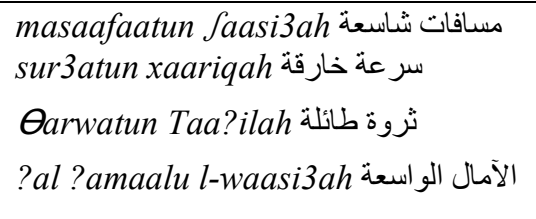 \\
\hline $\begin{array}{l}\text { heavy rainfall } \\
\text { heavy seas } \\
\text { heavy meal } \\
\text { heavy smoker } \\
\text { heavy industry }\end{array}$ & 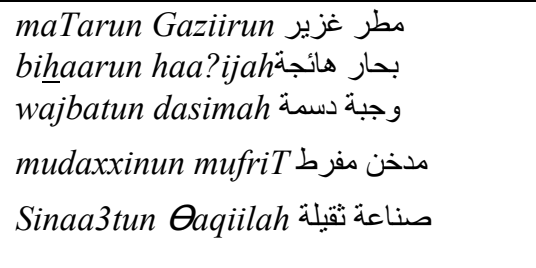 \\
\hline
\end{tabular}

What we see in this little lexical comparison of Arabic and English is that Arabic may have multiple collocational forms versus a single English form. For instance, while the word hoof collocates with the feet of the animals horse, cow and camel, Arabic sets aside a special collocational term for each animal so that haafiru goes with hiSaan (horse), Dalaf with baqarah (cow), and xuff with ba3iir (camel); the three Arabic words mean the same thing, hoof. The multiplicity of Arabic collocations to mean a single collocational item holds true for the remaining examples in the table and this is what seemingly creates divergence.

It is clear that the lack of correspondence between the two languages has always been a source of problems. These problems are mainly attributed to negative interlingual transfer. A good classification of the errors based on this negative transfer is furnished by Mahmoud (2005), part of which is illustrated below:

\section{Incorrect Preposition Errors:}

* by this way (in) - * by money (for) - * in the phone (on) - * on contact (in) -* ends with (in).

\section{The incorrect lexical collocations errors (Adjective+Noun combinations):}

* large thinking - * artificial information - * complete life - * a small accident

Word Choice Errors: (the choice of one word or both words is incorrect)

(A) One word incorrect

* repair his mistake - * make the homework - * pray the prayers.

(B) Both words incorrect

* destroyed houses (= broken homes), ${ }^{*}$ basic machine (= important device), ${ }^{*}$ hurts the mind (= harms the brain).

Word Form Errors: (the form of a word is incorrect)

* wants to get marriage * a famous musician band, * his economical problems.

Contextual Errors: linguistically correct but contextually incorrect

* bring a boy (= give birth to a boy), * lose dignity (= lose virginity), ${ }^{*}$ finish business (= do business).

Collocation incongruence may go even beyond those illustrated above. It has proven to be sensitive to structural issues including word class and word order. Trotter (2000) cites the following cases of divergence in Arabic and English based on the factors above. For example, while the singularast ?ad-damm (the blood) collocates with the

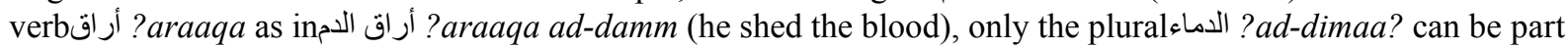
of the noun collocation إراقة الدماء?iraaqatu l-dimaa? (bloodshed). Shamaa (1978, p. 49) exemplifies word-order divergence as represented by Arabic phrases such as إبر و دبابيس 2ibar wa dababiis (Lit. needles and pins; pins and 
needles in English), and بالماء والصابون bilmaa?i wa S-Sabuun (Lit. with water and soap; with soap and water in English).

Metaphorical collocation also presents lots of problems in translation. While some metaphorical collocations are congruent in both languages (e.g. he shed crocodile tears (English) and يذرف دموع التماسيح yadrifu dumuи3a t-tamasiih (Arabic), others may vary (e.g., warm the heart (English) and ئلج الصدر yuOliju S-Sadr (lit.) cool the chest (Arabic)) (Trotter, 2000).

Based on the discussion above, it is clear that collocations constitute big linguistic hurdles for learners and translators. In view of the problems collocations pose for language learners, collocation dictionaries have come to be very crucial. The following sub-section discusses some collocational reference works in English and Arabic.

\subsection{An Overview of Prominent English Collocation Dictionaries}

Collocation dictionaries play a pivotal role in language learning and translation. Fakhouri (1995) emphasizes that one of the reasons why students err in translating collocation equivalents is the lack of bilingual dictionaries in collocations. Nofal (2012) attributes translators' failure to call up collocation counterparts in target language partly to lack of collocation dictionaries, a problem which leads them to use strategies such as reduction, synonymy, compensation, paraphrase and transfer (p. 75). According to Walker (2009, p. 281), the sources of information about collocations for a student learning English in a structured setting are the teacher, the course book and the dictionary.

English, a well-served language in terms of collocation studies, has a lot of collocation dictionaries, foremost among which are the BBI Dictionary of English Word Combinations (1997), the Oxford Collocations Dictionary for Students of English (2002) (OCD), and the LTP Dictionary of Selected Collocations (1999).The first two dictionaries are particularly prominent works. The following part briefly goes over these two works to get a flavor of collocation dictionaries in English.

Based on its revised edition (2011), BBI Combinatory Dictionary of English, initially released in 1986, is one of the great works on collocation. The dictionary, which includes thousands of entries and combinations, is a handy tool of dealing with the English language, in addition to being comprehensive in covering both grammatical and lexical collocations. As explained by the BBI editors, grammatical collocations are those that consist of a dominant word - noun, adjective/participle, verb - and a preposition or a grammatical construction, while lexical collocations are structures of types such as verb + noun, adjective + noun, noun + verb, noun + noun, adverb + adjective, and adverb +verb. Besides being of a highly didactic value and helping language learners, teachers and translators, BBI maintains a meticulous arrangement of and detailed information on entries. It also offers appreciable explanatory notes (Usage Notes) that help learners get the right collocations for words of various types.

The other important dictionary of collocations in English is LTP Dictionary of Selected Collocations (1997) by Hill and Lewis. It is of much assistance to learners in mastering vocabulary more effectively since it helps learners speak and write more naturally. The dictionary is particularly based on common strong collocations, excluding technical collocations from specialist areas such as medicine or economics. The collocations are so easily presented that most grammatical notes are excluded. The most important types listed in the dictionary are: adjective + noun (e.g., fatal accident, golden opportunity); verb + noun (e.g., accept responsibility, undermine (my) self-confidence); noun + verb (e.g., the gap widened, a fight broke out); adverb + adjective (e.g., highly desirable. potentially embarrassing); and verb + adverb (e.g., discuss calmly, lead eventually to).

The brief presentation of the two English dictionaries above reflects the special care English offers for collocations. English collocations have always been easily accessible to users of the language, the exact reverse of the situation in Arabic where Arabic collocations are not readily easily reached. One of the reasons is that Arabic collocation resources are not neatly arranged in a modern dictionary form. The following brief part overviews Arabic early efforts in tackling collocation structures.

\subsection{Early Arabic Thematic Dictionaries Featuring Some Collocation Material}

According to Emery (1988, 1991; quoted in Brashi, 2005, p.46) Arabic is a language rich in collocations and classical lexicographical works, such as فقه اللغة Fiqhu l-lughah (Philology) by Al-thaalibi (1986) and المخصص Al-mukhassas (the Categorized /Specialized) dictionary by Ibn Sidah (1996), أدب الكاتب Adabu l-kaatib (the Writer's Literature) by Ibn Qutaybah (1963) and Mabadi'au l-lughah مبادى اللغة (Principles of Language) by Al-Iskafi (1906) included plenty of collocation material.

Ibn Qutaybah's Adabu l-kaatib (the Writer's Literature), is divided into three parts, each of which is topically arranged to provide various advice for composers as to how to tackle issues relevant to lexical differences, 
morphological derivatives and semantic nuances. Although the book has a wealth of linguistic information with scattered pieces on collocation, it is not readily accessible for language learners to get information on collocation since it is not alphabetically arranged and does not follow a logical order and merely puts together lexical items of relevance only to scattered subjects (Haywood, 1965).

Al-thaalibi's Fiqhu l-lughah (philology), is made up of two main parts, the first of which includes 30 sub-parts made of 600 small chapters, while the second part comprises only 99 chapters. The parts and the chapters of the book are more logically ordered than those of Adabu l-kaatib. The two parts are collections of different linguistic information of various aspects (lexical, morphological and semantic). The book, topically arranged, can be thought of as thesaurus, a lexical dictionary or even a mini- encyclopedia (Al-Ayoubi, 2010). It includes descriptions of physical and abstract issues, giving portrayals of women, mountains, camels, houses, foods, rain, clouds, sand, dust, and characterizations of love, time, heights, depths, etc. The book is rich in linguistic information in general, and although it encompasses information on collocations, it is of limited use to learners and translators given its chaotic format.

Mabadi'au l-lughah (Principles of Language) by Al-Iskafi was hailed by Haywood (1965) on the grounds of being logically arranged. It starts by tackling natural phenomena, e.g., stars, constellations, time, night and day, and then lists various information on various issues including clothes, implements, food, drink and weapons. The words related to the animal world of horses, camels, lions, and other animals are also dealt with in the reference work. The final section discusses rare words from poetry and offers a detailed account of their senses (Haywood, quoted in Brashi, 48). Again the lack of archiving and search tools causes this work to be of little value to collocation seekers.

Al-mukhassas dictionary (the Categorized/Specialized) by Ibn Sidah is one of the renowned works intended for orators and writers. It was arranged by subject headings. The compiler started with human beings and the things that concern them, including clothes, food, sleep, weapons and fighting. Then, he moved on to animals and plants, and to social life issues, e.g. travel, work and play. The last section, however, tackles merely linguistic issues such as morphology and syntax. Although one may get some information on Arabic collocations here and there in the dictionary, it is still of limited value to language users.

As it appears from the brief overview of the Arabic references above, those works can never be considered dictionaries in the strict sense of the word. They have been criticized on the grounds that "the arrangement of the material is often idiosyncratic and unsystematic...obsolete and no longer relevant to Modern Standard Arabic" (Brashi, p. 89). The dictionaries above as Haywood (1965; quoted in Brashi) explains are only general classified vocabulary arranged according to subject heading in accordance with Arabic lexicographers' chief aim at this time, which is to merely register generic vocabulary.

Moving to modern Arabic lexicographic works, Wehr's Dictionary of Modern Written Arabic: Arabic-English (1979) has been particularly lauded for including some information about collocation terms. However, this dictionary is not arranged as an independent dictionary of collocations and does not seem to help learners of Arabic in this respect (Nofal, 2012, p. 89). This may be the case not only for Wehr's work, but also for most general purpose dictionaries. The reason for this may be partly attributed to space limitation (Brashi, 2005, p. 246). Another reason provided by Cowie (1981, p. 225) is that "it is doubtful whether, in the face of continuing user conservatism, lexicographers will undertake an ambitious treatment of collocations in general pedagogical dictionaries".

Arabic was, then, in need of modern specialized dictionaries that can tackle collocations in a systematic and arranged way catering for the needs of language learners and translators. The two dictionaries under study, Dar El-Ilm's Dictionary of Collocations (DEDC) and Al-Hafiz Arabic Collocations Dictionary (AACD), came to fill this gap in MSA. In sections 5 and 6, the researcher analyzes the two collocation dictionaries, assess their benefits to language users and translators, and present the issues that must be addressed so that they can be of greater assistance to language users.

\section{The Problem and Significance of the Study}

It is obvious from the previous introduction that Arabic badly-needed collocation dictionaries help language learners and translators; hence practitioners awaited the advent of DEDC and AACD to the language arena. However, these two works have not been closely scrutinized and their fundamental weaknesses have not been identified. The study particularly focuses on two major problems that beset the two references. DEDC's main problem is the compiler's rendering of some English collocation entries into Arabic free combinations, overlooking the fact that Arabic possesses ready collocations that can supplant the free word combinations given. With respect to AACD, the main issue is the shortage of the collocation range covered in the work, which 
renders it a meager source of collocation material.

The importance of the study stems from being probably one of the pioneering studies on analyzing and critiquing Arabic collocation dictionaries. To the best of the researcher's knowledge, this study is pioneering in tackling the collocation dictionaries that involve both English and Arabic. It fills a serious gap in the literature that has been overlooked ever since the two dictionaries were first compiled. This is intended to show the advantages of Arabic collocation dictionaries and call to attention their perceived shortcomings. The modifications and suggestions furthered by the study will be of great value to both language learners and translators who would be saved the effort of looking for the appropriate collocations in Arabic. It is hoped that revised editions of the dictionaries under investigation will make use of the observations in the study to overcome any drawbacks.

\section{Method}

Given the nature of the current qualitative, analytic work, an eclectic approach will be used utilizing descriptiveanalytic methods. It describes the characteristics of collocations, addresses the main features of collocation dictionaries and analyzes how collocations are treated linguistically and lexicographically. This is done in order to gain a better understanding of the treatment of collocations in Arabic dictionaries as well as the types of problems they pose for language learners and translators.

\section{Scope and Delimitations of the Study}

The paper is delimited to the study of two collocation dictionaries, namely Dar El-Ilm's Dictionary of Collocations (DEDC) (English-Arabic) (2007) by Dr. Hasan Ghazala and Al-Hafiz Arabic Collocations Dictionary (AACD) (Arabic-English) (2004) by Dr. Al-Tahir A. Hafiz. Since Arabic is the main focus of the study, the work is limited only to those two works being the only available dictionaries devoted to Arabic collocations. It is hoped that by focusing on those only available works, future attempts with collocation dictionaries will maximize benefits and make up the deficiencies pointed out by the current study.

\section{An Analysis of the Two Arabic Dictionaries}

The two sub-sections below give an analysis of the main components of the two dictionaries under study and demonstrate the potentials the two works have for users.

\subsection{Dar El-Ilm's Dictionary of Collocations (DEDC)}

Dar El-Ilm's Dictionary of Collocations is an English-Arabic dictionary based on multiple famous standardized sources of English collocations including the BBI Combinatory Dictionary of English (Benson et al., p. 1987), the LTP Dictionary of Selected Collocations (Hill et al. (eds.), p. 1997) as well as other mono-lingual (English-English) and bilingual (English-Arabic) general purpose dictionaries. The dictionary is compiled, as Ghazala states in his introduction to the work, to address the poor performance of language users in connection with collocations. The dictionary acts as a guide to users of English and Arabic to correctly use collocations, providing thousands of English examples, all translated into Arabic.

The dictionary's scope, targeting general as well as specialized readership, covers collocations of all types of texts: general, legal, political, journalistic, administrative, abstract, literary, non-literary; scientific/technical, medical, advertising, linguistic, translational, etc. It includes over $(12,000)$ entries with $(120,000)$ English collocations, translated into over $(150,000)$ Arabic equivalent collocations. The dictionary has a wide scope of coverage including the following types of collocations: verb-noun collocations; adjective-noun collocations; noun-verb collocations; of-genitive/ prepositional collocations; idiomatic collocations; and other miscellaneous collocations.

Ghazala believes that this work is likely to improve students' knowledge of both languages, particularly as regards how to correctly match words to one another, citing the deterioration of the use of collocations in Arabic as another reason for embarking on the dictionary project. He believes that collocation problems pervade the usage of Arabic in genres as varied as mass media, advertisements, conversation and colloquial literature. The dictionary, therefore, according to the compiler, fits the purpose of showing the beautifulness and effectiveness of using collocations.

The author cites the example of the mis-collocation of 'succeed' with 'exam' by Arabic speakers of English. Instead of using the collocation 'to pass the exam', it was found out that some translators and students of translation often make the mistake of using 'succeed in' with 'exam', influenced by the Arabic translation في لجح الإن najaha fii l-ixtibaar, and the mistranslation of 'to pass an exam' as تخطى الاختبار taxaTTaa l-ixtibaar. The same miscollocation problem is also observed for the case of 'to pass a law' translated as يمرر قانونا yumarriru qanuunan, which deviates in translation from the collocational Arabic يسن قانونا yasunnu qaanunan (p. 18). 
Since one of the main aims of the dictionary is to help users find collocations in Arabic that are equivalent in to the English counterparts, as explained in the case of 'pass the test' cited above, the lexicographer asserts the necessity of finding equivalent Arabic collocations to their English counterparts. For example, Ghazala complains about the translation of 'good reason' in English as سبب جيد sababun jayyid, seeing this as foreignness, ignorance and disregard of the existence of many Arabic collocations such as سبب وجيه/سبب منطقي/سبب معقول/سبب a قوي/ سبب مقبول sababun wajiih/sababun manTiqiy/ sababun ma3quul/ sababun qawiy/sababun maqbuul. The compiler sees collocations as 'beautiful' expressions that should be used to replace stale and ordinary language; the author gives a sample list of expressions where ordinary phrases must be replaced by more acceptable collocations:

\begin{tabular}{|c|c|}
\hline لغة عادية)(ordinary language/free combinations & متلازمات لفظية Collocations \\
\hline yقبر / يتخذ قرارهyuqarriru /yattaxidu qaraarah & يحزم أمره yahzimu?amrah \\
\hline بيسحرarhar & yaslubu l-lubb يسلب اللب \\
\hline أصعوبة بالغة biSu3uubatin baaliGah & iqqi l-nafs $\int$ bi \\
\hline 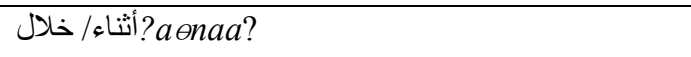 & fii GuDuun/ fii bahrr \\
\hline شاعجاع /صامدujaa3 /Saamid S & Oابت القلب و القدم Oaabitu l-qalbi wa l-qadam \\
\hline Da3iifun jiddan & $\begin{array}{l}\text { أوهن من بيت العنكبوت ?awhanu min bayti } \\
\text { l-3ankabuut }\end{array}$ \\
\hline & أيعرض yu3arriDu bi-?ahadihim \\
\hline maw Ouuq & مأمون الجانب ma?munnu l-janib \\
\hline مفاجرfaajir_ & suliiTu l-saan \\
\hline 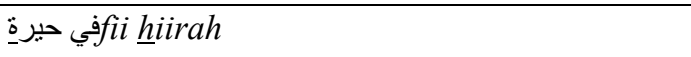 & fii haySi bayS \\
\hline Gadiba Gadaban Sadiidan & haaja wa maaja \\
\hline باختصار bixtiSaar & xulaaSatu l-qawl خلاصة القول \\
\hline Sawtu r-riih & مزيم الريح haziimu r-riilh \\
\hline haziimatun kabiirah & هزيمة نكر اء haziimatun nakraa? \\
\hline يخاف خوفا شديدا & ترتعد فر ائصده tarta3idu faraa?iSuh \\
\hline كاداه $3 a a d a a h$ & ناصبه العداء naaSabahu l-3adaa? \\
\hline
\end{tabular}

The dictionary's main aim, as understood from the exposition above, is to present English collocations with possible Arabic equivalent collocations, and as the list above shows, the compiler asserts appropriate Arabic collocations must be provided to match the English collocations. It will turn out, however, that the dictionary's main problem is using free combinations to translate English collocations where more appropriate Arabic collocations are possible, a problem which we return to in section 6 .

\subsection{Al-Hafiz Arabic Collocations Dictionary (AACD)}

Al-Hafiz Arabic Collocations Dictionary (AACD) (Arabic-English) is intended for Arabic-speaking learners of English and English-speaking learners of Arabic who may not have to learn, for example, which verbs are used with which nouns; the compiler believes that an Arabic collocation dictionary would help learners and users stay

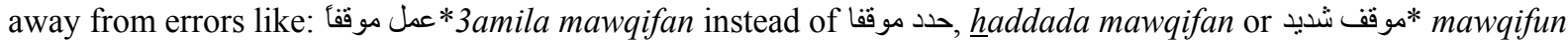
Sadiid instead of موقف حازم mawqifun haazim.

The dictionary specifically targets advanced learners of the language (often diplomats, professionals and gentlemen) so that they can save themselves such embarrassing errors as: صنعت مو عدا" Sana3tu maw3idan

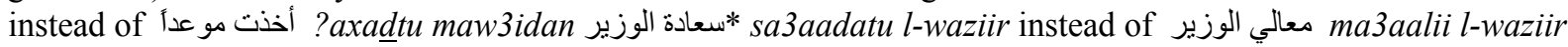
or طبح الكتاب Taba3a l-kitaab. The lexicographer excludes from his Arabic collocations dictionary open collocations (e.g. بيت جميل baytun jamiil; أكل طعابـ, ?akala Ta3aaman etc.) based on the assumption that they are freely used. This dictionary, therefore, as the compiler claims, is limited to restricted collocations (e.g., نشب nafab) and bound collocations (e.g., ضروس Daruus short idioms (e.g., الحرب الباردة ?alharbu l-baaridah). 
According to the lexicographer, AACD is limited to finding out "which particular co-occurrences in Arabic whose English equivalents are not exactly the same as the simple combinations of the English equivalents of the given collocation's lexical constituents" (p. 11).

As to the scope of coverage, Al-Hafiz states that the Arabic collocations entered in the dictionary include various part-of-speech combinations. The following is a list of the collocation combination included in the dictionary.

1. Verb + noun, where the noun can be the subject, e.g. هدأ الموج, hada?a l-mawj, the object, e.g., ضرب الخيمة Daraba l-xaymah or (حال) a state, e.g. استثاط غضباً ?ista SaaTa GaDaban. This combination composes a large section of Arabic collocations as almost every single verb in the language has its own numerous noun collocates.

2. Verb + prepositional noun phrase, where the noun is the indirect object (e.g. استقال من عمله ?istaqaala min 3amalih, بيت له أمرا bayyata lahu? amran.

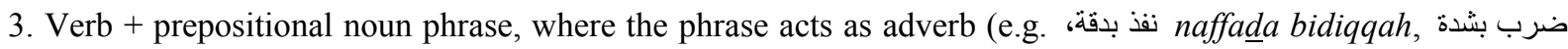
Daraba bifiddah).

4. Verb + noun phrase, where the noun is in the form of adverbial condition (e.g. اتصل هاتفياً /برقيَ ?ittaSala haatifiyyan, خاطب كتابياً xaaTaba kitabiyyan).

5. Verb + conjunction + verb, usually synonymous (e.g. هاب وماج haaja wa maaj، طار وحط Taara wa hallaq ).

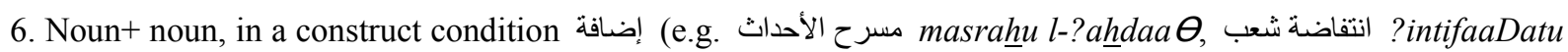
$\left.\int a 3 b.\right)$

7. Noun + conjunction + noun (e.g. تنظيف وترتيب tanDiifun wa tratiib, عزم وإصرار 3 عazmun wa ?iSraar .

8. Noun + adjective (e.g. جوى عظمى quwaa 3uDmaa, جمال أخاذ jamaalun ?axxaad.

9. Noun + prepositional noun phrase (e.g. غاية في الأدب Gaayatun fii l-?adab, حفنة من المال فiffnatun min al-maal.

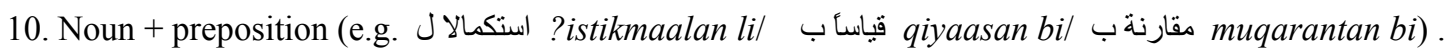

11. Adjective + noun (e.g. كبير القلب kabiiru l-qalb ، حسن الأخلاق hasanu l-?axlaaq.

12. Adjective + adverbial phrase, where the adverbial phrase consists of prep + noun (e.g. مستنكر بشدة mustankarun bi-fiddah, العجيب في الأمر?al3ajiibu fii 1-?amr.

Despite the wide range the compiler promises to present in his work, it will be pointed out in the following section that the main problem with this dictionary is the observed shortage in covering collocation items; only a small range of wide collocational possibilities in Arabic is presented.

Based on this overview of the two dictionaries, DEDC and AACD are welcome newcomers to the area of Arabic collocations; they offer users very good opportunities to make use of them, relieving them from the onus of having to look for the appropriate collocates of core words. However, the two dictionaries seem to have serious deficiencies from certain aspects, which the following section tackles, and which will also be the main focus of the paper.

\section{Problems with the Two Dictionaries}

\subsection{Problems with Dar El-Ilm's Dictionary of Collocations (DEDC)}

It must be stated in the very beginning that this work is more comprehensive and more extensive than Hafiz's work; the reason may be ascribed to the fact that the author started by collecting English collocations from various sources (see 5.1); however, the main problem of this dictionary is overlooking available Arabic collocations that would otherwise add more richness to the dictionary and render it more beneficial and useful to users. This point will be illustrated below. This dictionary sometimes uses ordinary language (i.e. free combinations) as translation of the English collocations while meticulous search in Arabic sources can offer more appropriate Arabic collocations that can supplant such ordinary language and make the dictionary more functional to Arabic users. In the examples offered to display that collocations are habitual co-occurrence of certain structures and that they are different from free collocations, part of which we repeat in Table 1 below, the lexicographer made very clear the difference between the two structures. 
Table 1. Ghazala's differentiation of ordinary language and collocations

\begin{tabular}{|c|c|}
\hline ordinary language لغة عادية oغ & متلازمات لفظية \\
\hline بيقر / ينذذ قرارهyuqarriru/ yattaxidu qaraarah & يحزم أمره yahzimu ?amrah \\
\hline yashar & yaslubu l-lubb \\
\hline biSu3uubatin baaligah بصعوبة بالغة & بشق النفس iqqi n-nafs $\int$ bi \\
\hline 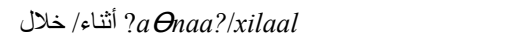 & fii GuDuun/ fii bahlrr \\
\hline ش شجاع/صامد & Oaabitu l-qalbi wa l-qadam ثابت القلب والقدم \\
\hline Da3iifun jiddan & a awhanu min bayti l-3ankabuut أوهن من بيت العنكبوت \\
\hline ينتقد أحدهم yantaqidu ?ahadahum & yu3arriDu bi-?ahadihim يعرض بأحدهم \\
\hline
\end{tabular}

He, thus, makes clear the difference between what 'ordinary language' is (i.e. free combinations) and what collocations are. Ironically, when he came to actual practice of translating similar collocational expressions from English into Arabic in his dictionary, the lexicographer did not practise what he preached; he made the same error he warned writers and speakers of. The current part of the section is a discussion of 265 subentries of the core words FEAR (125 subentries) and HOPE (140 subentries) and their collocates. The discussion shows how the lexicographer sometimes ignores ready Arabic collocations and uses free Arabic combinations instead.

Looking at the 125 subentries for FEAR in all their nominal and verbal structures, we find that Ghazala translated many English collocations of this entry into Arabic as free combinations. For example, for $\mathrm{V}+\mathrm{N}$ structures, he used free combinations instead of using more appropriate collocations already available in Arabic. Table 2 shows DEDC examples of V+N English collocations and their Arabic counterparts.

Table 2. Examples from DEDC of translating V+N structures for the entry FEAR

\begin{tabular}{|c|c|}
\hline ENTRY (FEAR) & DEDC TRANSLATION \\
\hline Fear & Xawf/raw3/xiSyah \\
\hline To arouse fear & yuOiiru l-xawf \\
\hline To be obsessed by & yuSaabu bihaajisi l-xawflyatalabbasuhu l-xawf يصاب بهاجس الخوف ، يتلبسه الخوف \\
\hline To be overcome by & yajtahuhuhu l-xawf \\
\hline To cause $\sim$ & yusabbibu l-xawf \\
\hline To develop & بصاب بالخوف yuSaabu bi-l-xawf \\
\hline To disguise $\sim$ & | بخفي الخوف yuxfii l-xawf \\
\hline To ease $\sim$ & يخفة/يهديء من خوف /روع yuxaffifu min xawf/yuhaddi?u min xawf/yuhaddi?u min raw3 \\
\hline To experience fear & yamurru bitajribati xawf/yujarribu l-xawf \\
\hline To feel fear & yuhissu bi-lxawf/ya S3uru bi-lxawf \\
\hline To have fears & yatmallakuhu /yantaabuhu/ya/3uru bi-l-xawf \\
\hline To hide $\sim$ & ب yuxfii l-xawf يخفي الخوف \\
\hline to strike $\sim$ into smb & 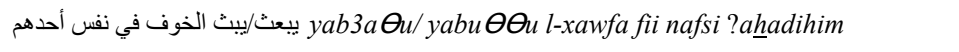 \\
\hline To suffer from & يعاني من مرارة الخوف yu3aanii min maraarati l-xawf \\
\hline
\end{tabular}

As we see from Table 2, most translations are merely not Arabic collocates but free combinations. For example, it is very clear that يسبب الخوفyusabbibu l-xawf, يصاب بالخوف yuSaabu bi-lxawf, يجرب الخوف yujarribu l-xawf, and yuxfii l-xawf are far from being Arabic collocations; they do not sound natural Arabic. It would be more beneficial for translators and learners of AFL/ASL to have parallel collocations for the English ones. This is not an impossible task since Arabic has a good legacy of collocations though not in a dictionary form; Table 3 below shows a list of alternative collocations (Note 1) to the free combinations given by the lexicographer in Table 1. 
Table 3. Alternative collocations to those in Table 2

\begin{tabular}{|c|c|}
\hline ENTRY (FEAR) & ALTERNATIVE TRANSLATION \\
\hline To arouse fear & يرونيرurawwi3 \\
\hline To be obsessed by & li3taraahu l-wajal \\
\hline To be overcome by & yanqabiDu min al-xawf \\
\hline To cause $\sim$ & 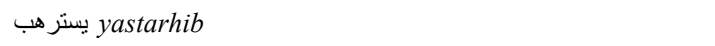 \\
\hline To develop $\sim$ & يتوجس yatwajjas \\
\hline To disguise & yuDmiru maxaawifahu \\
\hline To ease $\sim$ & أفرخ روعه \\
\hline To experience fear & yasta/3iru xi Siyat \\
\hline To feel fear & yasta/3iru maxaafat/?axadathu ri3daah يستشعر مخافة، أخذته رعدة \\
\hline To have fears & تعتريه الأوجال ta3tariihu l-?awjaal \\
\hline To hide $\sim$ & yuDmiru maxaafata S-Say? \\
\hline to strike $\sim$ into smb & nazala r-ru3bu fii qalbih \\
\hline To suffer from & balaGati l-quluubu l-hanaajir \\
\hline
\end{tabular}

Table 4 shows the lexicographer's translations (free combinations) vis-a-vis alternative real Arabic collocates.

Table 4. The lexicographer's translations vs. alternative Arabic collocates

\begin{tabular}{|c|c|c|}
\hline ENTRY (FEAR) & DEDC TRANSLATION & ALTERNATIVE TRANSLATION \\
\hline To arouse fear & yuOiiru l-xawf & يرونيurawwi3 \\
\hline To be obsessed by $\sim$ & $\begin{array}{l}\text { يتلبسه الخوف /يصاب بهاجس الخوف } \\
\text { yuSaabu bi-haajisi/yatalabbasuhu l-xawf }\end{array}$ & 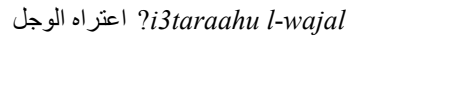 \\
\hline To be overcome by $\sim$ & يجتاحه الخوفyajtahu l-xawf & yanqabiDu mina l-xawf ينقبض من الخوف \\
\hline To cause $\sim$ & yusabbibu l-xawf يسبب الخوف & بastarhib يستر هب \\
\hline To develop & yuSaabu bi-lxawf & بatawajjas يتوجس \\
\hline To disguise $\sim$ & يخفي الخوف yuxfii l-xawf & يضمر مخاوفه yuDmiru maxaawifahu \\
\hline To ease $\sim$ & 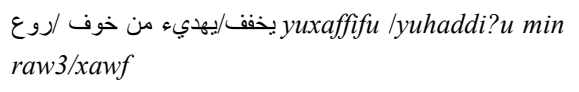 & afraxa raw3ahu \\
\hline To experience fear & $\begin{array}{l}\text { يمر بتجربة خوف،يجرب الخوف yamurru bitajribati } \\
\text { xawffyujarribu l-xawf }\end{array}$ & يستشعر خشية \\
\hline To feel fear & & $\begin{array}{l}\text { بستشعر مخافة، أخذته رعدة } \\
\text { yasta Siru maxaafat/?axadathu ri3dah }\end{array}$ \\
\hline To have fears & $\begin{array}{l}\text { يتملكه/ ينتابه الخوف/يشعر بالخوف } \quad \text { l-xawflya/3uru } \\
\text { yatamallakuhu } \quad \text { lyantabuhu } \\
\text { bil-xawf }\end{array}$ & تعتريه الأوجال ta3tariihu l-?awjaal \\
\hline To hide $~$ & بخفي الخوفyuxfii l-xawf & $\begin{array}{l}\text { يضمر مخافة الثيءyuDmiru maxaafata } \\
\text { S-Say? }\end{array}$ \\
\hline to strike $\sim$ into smb & 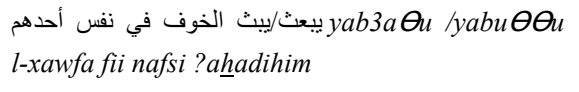 & nazala r-ru3bu fii qalbih نزل الرعب في قلبه \\
\hline To suffer from & بعyu3aanii min maraarati l-xawf & $\begin{array}{l}\text { l-halaGat il-quluubu } \\
\text { l-hanajir }\end{array}$ \\
\hline
\end{tabular}

As it appears from the table above, the alternative translations are closer to being collocations in Arabic than 
those offered by the lexicographer. To take a few examples from the table above, it is more natural, for example, to say يصاب بهاجس الخوف yuSaabu bi-haajisi l-xawf as a translation of the English collocation to be obsessed by fear. It is also more acceptable in Arabic to use يضمرمخاوفهyuDmiru maxaawifahu as a translation of the English expression to disguise fear than using the free structure يخفي الخوف yuxfii l-xawf. Also, يستشعر خشية yasta/3iru xafiyat is of more collocational nature as a translation of the English يمر بتجربة خوف . ئ collocation to experience fear than the stale expressions used in the DEDC dictionary, i.e yamurru bitajribati xawf and يجرب الخوف yujarribu l-xawf.

The same holds true for ADJ $+\mathrm{N}$ structures for the same entry. The following table shows lexicographer's translations and alternative collocations put together.

Table 5. DEDC translations vs. alternative Arabic collocates of N+ADJ FEAR collocates

\begin{tabular}{|c|c|c|}
\hline ENTRY & DEDC TRANSLATION & ALTERNATIVE TRANSLATION \\
\hline Chilling fear & 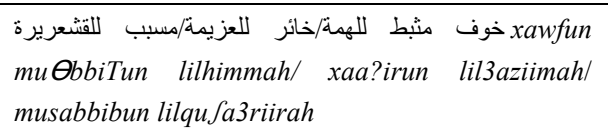 & $\begin{array}{l}\text { تقنشع له الجلود/ترتعش له الأيدي xawfun taqSa3irru lahu } \\
\text { l-juluud/tarta3ifu lahu l-?aydii }\end{array}$ \\
\hline Deep fear & خوف عميق/شديد xawfun 3amiiq / Sadiid & خوف ملء الضلوع xawfun mil?u D-Duluu3 \\
\hline Deep-seated fear & 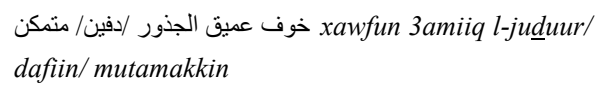 & خوف يشق الصدور xawfun yaJuqqu S-Suduur \\
\hline Dreadful fear & خوف مرعبxawfun mur3ib & $\begin{array}{l}\text { خوف نرتعد له الفر ائص } \\
\text { Xawfun tarta3idu lahu l-faraa?iS }\end{array}$ \\
\hline Grave fear & xawfun baaliG/Sadiid & xiifah /rahbah \\
\hline Great fear & خوف عظيم xawfun 3aDiim & xawfun yahtiku QamiSa l-qalb خوف يهil قميص القلب \\
\hline Idle fear & خوف خفي xawfun xafiy & خوف مضمر xawfun muDmar \\
\hline Immediate fear & Xوف مباشر / فوري & فزع/روع faza3 /raw3 \\
\hline Inarticulate fear & 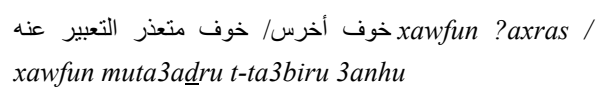 & xawfun ya3qidu l-lisaan \\
\hline Irrational fear & 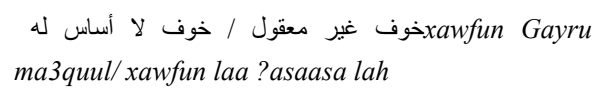 & Xوف يلجلج المنطق xawfun yulajliju l-manTiq \\
\hline Mortal fear & خوف مميت xawfun mumiit & $\begin{array}{l}\text { خوف يهنك حجاب القلب } \\
\text { Xawfun yahtiku hijaba l-qalb }\end{array}$ \\
\hline Strong fear & xawfun 3aDiim/ qawiy & روع شديد raw3un fadiid \\
\hline
\end{tabular}

If we compare DEDC translations to those suggested, we find that the translation offered to 'chilling fear', i.e. xawfun muOabbiTun lilhimmah/xaa?irun lil3aziimah/musabbibun

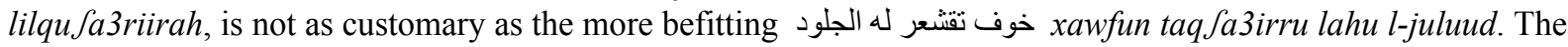
خوف xawfun 3amiiq/Sadiid as a translation of 'deep-seated fear' is less regular than خوف عميق الجذور expression

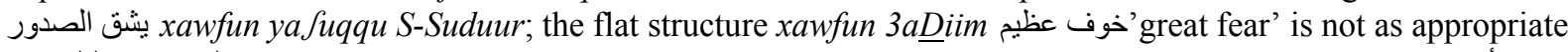

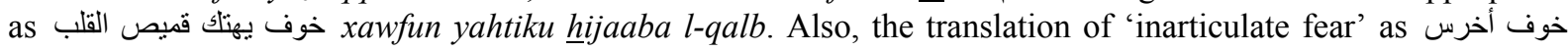
xawfun ?axras, is not as collocationally genuine as خوف يعقد اللسان xawfun ya3qidu l-lisaan. By the same token, 'strong fear' is better collocationally translated as روع شديد raw3un Sadiid than as خوف عظيم xawfun 3aDiim.

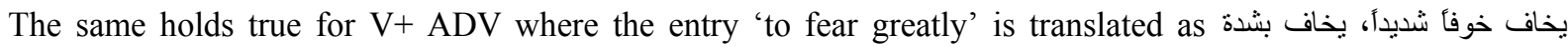
yaxaafu xawfan Sadiidan/bifiddah; and 'to fear very much' is given the translationl برتاع كثبرا جدان yartaa3u kaӨiiran jiddan. Using يخاف خوفأ شديدأ، يخاف بثدة yaxaafu xawfan Sadiidan/bifiddah as a translation of 'fear greatly' is again more of a free word combination than a spontaneous collocation; the use of يرتخ yartaa3 or ئوجس خوفأ yatawajjasu xawfan is probably more habitual and standard. The same is true of 'fear very much', commonly translated as يروتاع كثير ا جدا yartaa3u ka Aiiran jiddan, which is less typical than the more normal الأمر yurawwi3uhu l-?amr. Table 6 compares DEDC translations of V+ ADV combinations and the suggested ones. 
Table 6. DEDC FEAR+ ADV translations vs. alternative Arabic collocates

\begin{tabular}{|c|c|c|}
\hline ENTRY (FEAR) & DEDC TRANSLATION & ALTERNATIVE TRANSLATION \\
\hline To fear greatly & 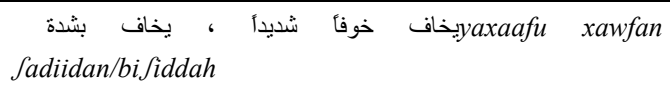 & 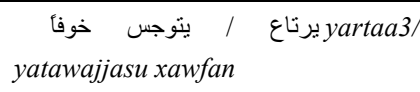 \\
\hline To fear very much & yartaa3u ka Oiiran jiddan يرتاع كثير ا جدا & yurawwi3uhu l-?amr يرو عهد الأمر \\
\hline
\end{tabular}

Moving on to another extensive entry, namely the entry for the word HOPE in all its structures (140 subentries), we find that the same situation is replicated here. What we see is that the lexicographer uses free word combinations instead of true Arabic collocations. Consider the following ' $\mathrm{V}+\mathrm{HOPE}$ ' list based on DEDC.

Table 7. Arabic Translation of V+HOPE list based on DEDC

\begin{tabular}{|c|c|}
\hline ENTRY (HOPE) & DEDC TRANSLATION \\
\hline To abandon hope & \\
\hline To arouse hope & yuӨiiru 1-?amal \\
\hline To have no hope & laa ?amala lah/laysa 3indahu ?amal \\
\hline To lose hope & yafqidu l-?amaml \\
\hline To nurse a hope & يحتضن الأمل / يضمر في الذاكرة أملا \\
\hline To restore hope & yasta3iidu l-?amal \\
\hline To retain hope & | يحافظ / ييقي على الأمل / yuhaafíDu/ yubiqii 3alaa l-?amal \\
\hline To revive hope & لينعش / يجدد الأمل yun3ifu/ yujaddidu l-?amal \\
\hline To see hope & ألأمل \\
\hline
\end{tabular}

Looking at some of the expressions above, we can see easily that the compiler translated the English collocations into 'ordinary' free combinations rather than collocational Arabic expressions. For example, the expression arouse hope, is translated as يثير الأمل yu Oiiru l-?amal which is not collocational; a more suitable expression would be يحيي ميت الآمال yuhiyii mayyita l-?amaal. The same applies to abandon hope and lose hope both translated as يقال الأمل الأبل naDaba rajaa?uh. The same is true of see hope translated as laahat fiihi baariqatu l-?amal. Table 7 compares the list of V+ hope collocation as translated by DEDC and how more fitting collocations can be used.

Table 8. DEDC V+HOPE collocation translations vs. alternative Arabic collocates

\begin{tabular}{|c|c|c|}
\hline ENTRY (HOPE) & DEDC TRANSLATION & ALTERNATIVE TRANSLATION \\
\hline To abandon hope & 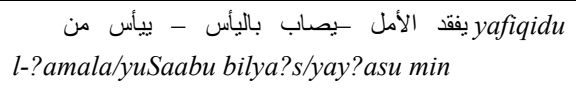 & قد qu خاب رجاؤه \\
\hline To arouse hope & yuOiiru l-?amal يثير الأمل & يحيب ميت الآمال \\
\hline To have no hope & $\begin{array}{l}\text { 3indahu ?amal laa ?amala lah/laysa } \\
\text { أمل له اليس عنده أله lala }\end{array}$ & 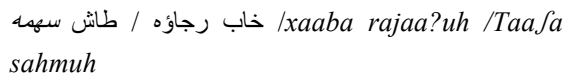 \\
\hline To lose hope & يفقد الأمل yafqidu l-?amala & 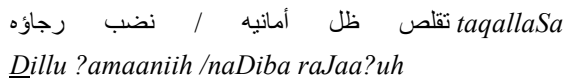 \\
\hline To nurse a hope & $\begin{array}{l}\text { يحتضن الأمل / بضمر في الذاكرة أملا yahtaDinu } \\
\text { l-?amal/yuDmiru fii z-zakirati ?amalan }\end{array}$ & $\begin{array}{l}\text { برصد برق الآمال } \\
\text { yarSudu barqa l-?amaal }\end{array}$ \\
\hline To restore hope & yasta3iidu l-?amal & ينعش عاثر الآمال yun3ifu 3aa Oira l-?amaal \\
\hline To retain hope & 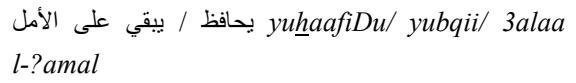 & yuhayyi?u bihi daawiya l-?amal يهي؟ به ذاوي الأمل \\
\hline To revive hope & yun3ifu/ yujaddidu l-?amal & يخضر عود الرجاء yaxDarru 3uudu r-rajaa? \\
\hline To see hope & yaraa l-?amal يرى الأمل & laahat baariqatu l-?amal لاحت بارقة الأمل \\
\hline
\end{tabular}


The same is also valid for the structure HOPE + V. As Table 9 shows, the English collocates are rendered into free Arabic combinations.

Table 9. Arabic Translation of HOPE $+\mathrm{V}$ list based on DEDC

\begin{tabular}{|c|c|}
\hline ENTRY (HOPE) & DEDC TRANSLATION \\
\hline Hope died & مات الأمل maata l-?amal \\
\hline Hope disappeared & Pixtafaa 1-?amal \\
\hline Hope dwindled & تضاءل الأمل taDaa?ala l-?amal \\
\hline Hope evaporated & tabaxxara?amaluh \\
\hline Hope faded & dawaa /dabula l-?amal \\
\hline Hope flourished & Inta3aSa l-?amal ?izdahar/ \\
\hline Hope grew & نما /كبر الأمل namaa /kabura l-?amal \\
\hline Hope persists & يدوم / يصمد الأمل yaduumu / yaSmidu l-?amal \\
\hline Hope receded & tralaa Saa/inhasra/xabat jadwat l-?amal \\
\hline Hope returned & عاد الأمل \\
\hline \multirow[t]{2}{*}{ Hope is running out } & يتلاشى الأمل/ ينضب معين الأمل / تقلص ظل أمانيه \\
\hline & yatalaa Saa l-?amal/yanDabu ma3iinu l-?amal/taqallaSa Dillu ?amaaniih \\
\hline Hope survived & 3aa Sa l-?amalu /baqiya l-?amalu hayyan \\
\hline
\end{tabular}

As we see from the table above, hope dwindled is translated as تضاءل الأمل taDaa?ala l-?amal while the more collocational Arabic term تقطعت به أسباب الأمل taqaTTa3at bihi l-?asbaab is disregarded. Also, the structure hope grew is translated as نما /كبر الأمل أمانيه zakaa manbatu ?amaalih. For the expression hope disappeared, آخفقت آماله dictionary. The expression عa عاش الأمل/ بقي الأمل حياً translation of the English collocation hope survived; a more appropriate translation is النتى نسيم الأنس nasiimu l-?amal. Furthermore, the translation of hope returned as alada l-?amal is a bit stale compared to the figurative and more collocational ثغور الآمال تبلج صبح المنى/برقت taballaja Subhu l-munaa/ baraqat OuGuuru $l$-? amaal. The following table presents the suggested collocations vis-a-vis the ones given by the lexicographer.

Table 10. DEDC HOPE + V collocation translations vs. alternative Arabic collocates

\begin{tabular}{|c|c|c|}
\hline ENTRY (HOPE) & DEDC TRANSLATION & ALTERNATIVE TRANSLATION \\
\hline Hope died & مات الأمل maata l-?amal & kadabat Dunuunuh كذبت ظنونه \\
\hline Hope disappeared & اختفى الأمل ixtafaa l-?amal & آخفقت آماله \\
\hline Hope dwindled & تضاءل الأمل taDaa?ala l-?amal & taqaTTa3at bihi l-?asbaab تقطعت به الأسباب \\
\hline Hope evaporated & tabxxra ?amaluh & Kذبه رائد الأمل kadabahu raa?idu l-?amal \\
\hline Hope faded & dawaa l-/dabula l-?amal ذوى / ذبل الأمل & عادت آماله أقلص من ظل حصاة \\
\hline & & 3aadat ?amaaluhu ?aqlaSa min Dilli haSaah \\
\hline Hope flourished & أزدهر / انتعش الأمل ?inta3aSa l-?amalu ?izdahar/ & $\begin{array}{l}\text { baraqat OuGuuru l-?amaal } \\
\text { برقت ثغور الآمال }\end{array}$ \\
\hline Hope grew & نما /كبر الأمل namaa /kabura l-?amal & $\begin{array}{l}\text { زكى منبت آمالد / أخصب زرع أمانيه ?amaalih/ ?axSaba zar3u ?amaaniih } \\
\text { Zakaa manbatu ?ama }\end{array}$ \\
\hline Hope persists & يدوم / يصمد الأمل yaduumu / yaSmidu l-?amalu & 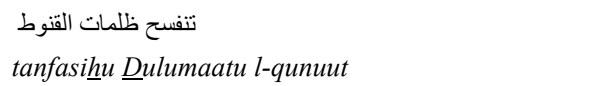 \\
\hline Hope receded & 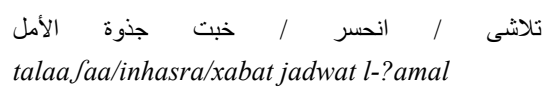 & تقوضت حصون آمالد \\
\hline Hope returned & عاد الأمل & 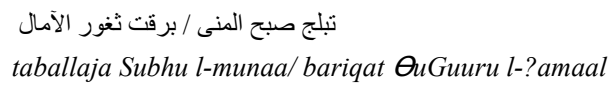 \\
\hline Hope survived & 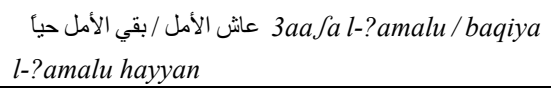 & $\begin{array}{l}\text { انتشى نسيم الأمل } \\
\text { ?inta Saa nasiimu l-?amal }\end{array}$ \\
\hline
\end{tabular}

For the collocation ADJ + N (ADJ+HOPE), the same observation can be equally made. A 'futile hope' is translated as أمل إبليس في الجنة /أمل عبثي ?amalun 3abaOii/ ?amalu ?ibliisa fii l-jannah, which is sort of free 
compared to the more figurative and original Arabic expression مل دونه شيب الغراب?amalun duunahu Saybu

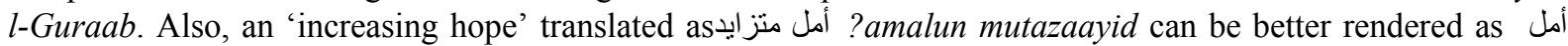

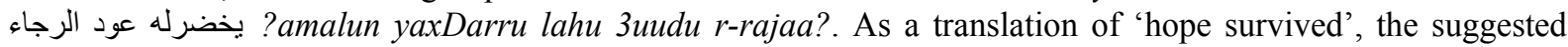

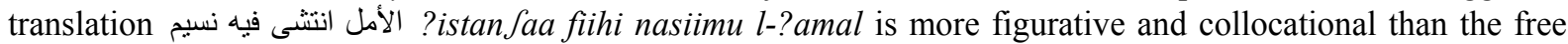
translation عaaSa l-?amalu/ baqiya l-?amalu hayyan. See Table 11 for possible alternatives.

Table 11. DEDC ADJ+HOPE collocation translations vs. alternative Arabic collocates

\begin{tabular}{|c|c|c|}
\hline ENTRY (HOPE) & DEDC TRANSLATION & ALTERNATIVE TRANSLATION \\
\hline A faint hope & أمل باهت / ضعيف ?amalun baahit /Da3iif & wasaawisu l-?aTmaa3 وساوس الأطماع \\
\hline A flickering hope & أمل بارق / خاطف ?amalun baariq /xaaTif & rajaa?un 3alaa Safiirin haar رجاء على شفير هار \\
\hline A frail hope & 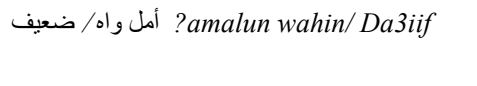 & $\begin{array}{l}\text { أمل دونه شيب الغراب ?amalun duunahu Saybu } \\
\text { l-Guraab }\end{array}$ \\
\hline A futile hope & ?amalun & 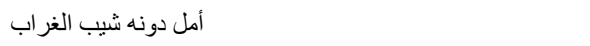 \\
\hline & 3aba Өii/ ?amalu ?ibliisa fii l-jannah & ?amalun duunahu Saybu l-Guraab \\
\hline A great hope & & $\begin{array}{l}\text { يضيق عنه نطاق الطمع } \\
\text { yaDiiqu 3anhu niTaaqu T-Tama3 }\end{array}$ \\
\hline An increasing hope & amalun mutazaayid & أمل يخضر له عود الرجاء \\
\hline A vain hope & 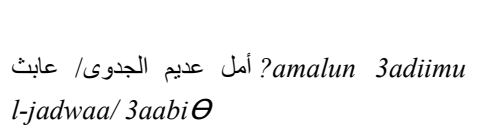 & $\begin{array}{l}\text { ?amalun yaxDarru lahu 3uudu r-rajaa? } \\
\text { أمل باطل?amalun baaTil }\end{array}$ \\
\hline
\end{tabular}

For V+ HOPE, complement collocations follow suit. The expression عنده أمل في أحده 3indahu ?amalun fii ? ahadihim as a translation of have hope in smb is stale compared to the more vibrant alternative استنشى فيه نسيم لأlistan Saa fiihi nasiimu l-?amal. The following table exemplifies DEDC translation of the English collocations and the alternative more acceptable variants.

Table 12. DEDC translations of V+HOPE complement collocation vs. alternative Arabic collocates

\begin{tabular}{|c|c|c|}
\hline ENTRY (HOPE) & DEDC TRANSLATION & ALTERNATIVE TRANSLATION \\
\hline Have high hopes for & 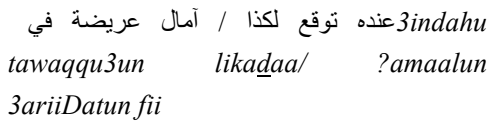 & طويل عنان الأمل Tawiilu 3anaani l-?amal \\
\hline To have hope in & 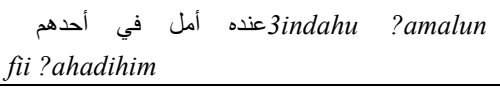 & $\begin{array}{l}\text { استنشى فيه نسيم الأمل? } \\
\text { ?istan aa fiihi nasiimu l-?amal }\end{array}$ \\
\hline
\end{tabular}

One big problem with the translation of the collocation above is the lexicographer's insistence on translating the collocational head word the same for all structures, which sometimes ends up being rather non-collocational Arabic and, thus, makes the item of less value to users.

To sum up, the main problem with this work, as we see it, is that English collocations are translated into Arabic free combinations; this does not mean, of course, that every collocation has to translate into an equivalent Arabic collocation, yet the problem is that the compiler insisted on translating many English collocations, as we see from the two entries under study, into Arabic free combinations where more suitable Arabic collocations are available. By so doing, the compiler somewhat failed to make full use of the massive legacy of collocations in Arabic to find equivalent or semi-equivalent Arabic collocations to the English ones.

\subsection{Problems with $A A C D$}

Moving to AACD for the same entries, FEAR and HOPE (140 subentries), we find that the main problem is the small range of collocation covered for each item. For instance, if we look up the entries for the equivalents of FEAR, we find that only two items are available, namely خاف xaafa and فزع fazi3a. The whole range of FEAR includes only the following items. 
Table 13. The core word خاف xafa and its collocates according to AACD

\begin{tabular}{|c|c|c|}
\hline ENTRY) (FEAR & English & Arabic example \\
\hline خاف على xaafa 3alaa & fear for & خافت عليه من البرد الثديد \\
\hline & & xaafat 3alayhi mina 1-bardi $\int-\int$ adiid \\
\hline خاف من xaafa min & be afraid of & يخاف معظم الناس من الظلام \\
\hline & & yaxaafu mu3Damu n-naasi mina Dalaam \\
\hline فزع من fazi3a min & to be frightened from & $\begin{array}{l}\text { فزعوا من صوت الصاروخ } \\
\text { fazi3uu min Sawti S-Saaruux }\end{array}$ \\
\hline
\end{tabular}

The main focus of the fear-equivalent items is on the phrasal verb structures of the two, i.e. خاف علىxaafa 3alaa, فز fazi3a min, completely overlooking the existence of multitude other structures involving خاف $x a a f a$ and فزع maxaafah. There is no reason why the range of FEAR is so limited in the dictionary; Arabic is known to be a rich language in terms of vocabulary and collocations. The following table includes a list of possible other structures of خوف xawf that could have been added and consequently made the work more fruitful.

Table 14. The core word خوف xawf and its collocates in AACD

\begin{tabular}{|c|c|}
\hline To arouse fear & yuقiiru l-xawf \\
\hline To be obsessed by fear & ya3tariihu l-wajal \\
\hline To be overcome by fear & yajtaahul-xawf \\
\hline To have fears & yيتملكه/ ينتابه الخوف/يشعر بالخوف yatamallakuhu /yantaabuhu/ya 3uru bi l-xawf \\
\hline To hide fear & yuDmiru l-xawf \\
\hline to strike fear into & nazala l-xawfu fii qalbih \\
\hline
\end{tabular}

The fact that this work included only a couple of examples about the verb خاف xaafa, to the exclusion of other derivatives of the verb makes this work totally deficient and minimizes its value for language users. Although the compiler promised that his dictionary would save advanced learners many embarrassing errors, it is expected that by eliminating so much material from the entries, learners would be at a loss as to Arabic equivalents of verbs like the ones in the table above. For the expression arouse fear, be obsessed by fear, be overcome by fear, to ease fear, the foreign students or learners of Arabic would not be able to hit the right collocation since they are not listed in the dictionary. It is not possible for foreigners, though advanced they may be, to find collocations without the help of a dictionary that can distinguish between the Arabic equivalents of, for example, nagging fear and strong fear; grave fear and great fear, deep fear and deep-seated fear.

This also applies to the entry أمل amal, HOPE, where only few examples (listed in Table 15) have been furnished as follows.

Table 15. The core word أمل ?amal and its collocates in AACD

\begin{tabular}{|c|c|c|}
\hline ENTRY (HOPE) & English & Arabic example \\
\hline $\begin{array}{l}\text { آمال -عريضة / عراض ?amaalun } \\
\text { 3ariiDah/3iraaD }\end{array}$ & High hopes & $\begin{array}{l}\text { للإنسان آمال عريضة بينما عمره في الدنيا قصيرlil?insaani ?amalun } \\
\text { 3ariidatun baynamaa 3umruhu fii d-dunya qaSiir }\end{array}$ \\
\hline ?amalun zaa?ifun & False hope & 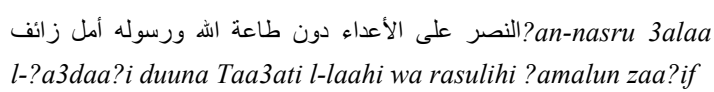 \\
\hline amalun manfuud & Pursued hope & $\begin{array}{l}\text { السلام في المنطقة هو الأمل المنشود } \\
\text { ?as-salaamu fii l-minTaqati huwaa l-?amalu l-manfuud }\end{array}$ \\
\hline رجاء -أن rajaa?a ?an & In the hope that & $\begin{array}{l}\text { أكرم الضيف رجاء أن يثفع له عند الأمير } \\
\text { ?ukrimu D-Dayfa rajaa?a ?an yaffa3a lahu 3inda l-?amiir }\end{array}$ \\
\hline
\end{tabular}

All derivatives of أمل amal are completely ignored; we do not see the Arabic equivalents of $\mathrm{V}+\mathrm{HOPE}$ collocations such as: abandon hope, arouse hope, restore hope, and revive hope. Nor do we see equivalents of HOPE $+\mathrm{V}$ collocations such as hope died, hope disappeared, hope evaporated, hope is running out, hope 
dwindled. All we come across in the dictionary are just ADJ+ HOPE structures, as appears from the table above. Even the list given completely bypasses other collocations that fall into the same category such as ?amalun baahit/ Da3iif 'a faint hope', أمل كبير/عظيم ?amalun kabiir/3aDiim 'a great hope', أمل متز ايد ?amalun mutazaayid 'an increasing hope'. Arabic is a rich language with those words as أمل 'amal. The following is a list of possible original collocations of the word in Arabic that were absent from the dictionary.

Table 16. Some common collocations of the word أمل -?amal in Arabic

\begin{tabular}{|c|c|}
\hline He has high hopes & طويل الأمل Tawiilu l-?amal \\
\hline He has high/ big hopes & فسيح رقعة الأمل fasiihu ruq3ati l-?amal \\
\hline He has wild hopes & طويل عنان الأمل Tawiilu 3anaani 1-?amal \\
\hline His wishes came true & tahaqqat il-?amaal تحققت الآمال \\
\hline His hopes are rising & سمت الآمال samat il-?amaal \\
\hline
\end{tabular}

Going beyond the two entries of FEAR and HOPE, we can find that the range of subentries for each main entry is very limited. For example the verb يئس ya? isa 'to be desperate' has only a single sub-entry, i.e. as a phrasal

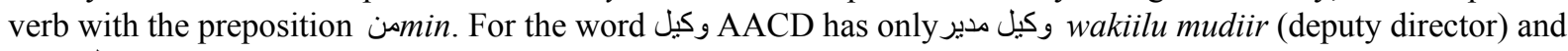
wakii 'awareness', the compiler lists only the N+ADJ وصل wasyun kaamil (complete awareness). For the verb وصي كامل wasala, the full entry of the item is only two subentries, i.e. وصي (to وصل رحمه waSala xabar (to come to one's knowledge), and waSala rahimah visit, and be good to, one's relatives).

وجه الثبه wajhu f-fabah (grounds of analogy), and وجه مستعار wajhun musta3aar (mask), completely passing over some very common collocations of wajh such as the ones in table 17.

Table 17. Some common collocations of وجه wajh in Arabic

\begin{tabular}{|c|c|}
\hline The right thing & wajhu S-Sawaab وجه الصواب \\
\hline It is completely pointless to oppose & llaa wajha li-li3tiraaD \\
\hline The sure thing, the only certainty & wajhu l-yaqiin \\
\hline (of ) a beautiful face & Sabiihuhu l-wajh \\
\hline (of ) a cheerful face & Talqu l-wajh \\
\hline (of ) a radiant face & mutahallilu l-wajh \\
\hline (of ) a shy face & Layyiyu l-wajh \\
\hline (of ) a lovely face & nadiyyu l-wajh \\
\hline To wander aimlessly & haama 3alaa wajhih \\
\hline His face darkened with anger & رra?aytu l-GaDaba fii wajhih أيت الغضب في وجهه \\
\hline I saw his furious face & ra?aytu l-hamiyyata fii wajhih رأيت الحمية في وجهه \\
\hline His face twisted & taGayyar wajhuh نغير وجهه \\
\hline His face went red & tama33ara wajhuh تمعر وجهه \\
\hline
\end{tabular}

For another very common noun in Arabic, the word كرم karam (generosity) has no more than a single subentry, i.e. كرم الأخلاق karamu l-?axlaaq (nobility of character). Arabic abounds in

many collocations of this word; here are some examples.

Table 18. Some common collocations of كرم karam (nobility) in Arabic

\begin{tabular}{|c|c|}
\hline Noble descent or origin & كرم الأصل karamu l-?aSl \\
\hline High morals & 年 amaa?il Jkaramu f- \\
\hline Incredibly generous & عinwaanu l-karam \\
\hline The symbol of generosity & rabiibu l-karam ربيب الكرم \\
\hline Unusual generosity & aryahiyyatu l-karam \\
\hline The icon of generosity/ origin of generosity & معدن الكرم ma3dinu l-karam \\
\hline
\end{tabular}


The fact that the item range for $A A C D$ is rather restricted has caused its use of original and legacy Arabic in this connection quite limited as well. Given the fact that the dictionary is an Arabic-English one, much work could have been done. Consulting Arabic thesauri, old and new, can provide the lexicographer with a wealth of lexical items in this connection. AACD, thus, lacks what specialized collocation dictionary should have. As Brashi (2005, p. 247) states"... specialized dictionaries would have to be comprehensive in covering the different usages of each word in the source language and their closest equivalent(s) in the target language. Moreover, these dictionaries would help their users to identify source language collocations and find quickly their target language equivalents". As we see from the examples above AACD entries seem to be quite deficient, which makes the dictionary of rather limited value to users. The lexicographer could not do enough to expand the subentries and extend the data of the work.

In sum, analyzing the DECD and AACD collocation dictionaries above shows that despite the real value the two works demonstrate, they suffer from some deficiencies that render them less useful to users than they are intended to be. The main two problems of both dictionaries, based on the analysis above, are using free Arabic combinations as equivalents of the corresponding English collocations although alternative Arabic collocations and formulaic structures are available (as appears from analyzing DECD), and the critical shortage of Arabic collocation presented for the items given, which is the main issue with AACD.

\section{Conclusion}

This research is about two Arabic collocation dictionaries, probably the only ones produced so far, and how they may be improved to the benefit of language learners. Based on the data analyzed in this work (more than 265 subentries of HOPE and FEAR, in addition to some other minor entries), it is pointed out that although the two current works are pioneering, mainly devoted to collocations, the dictionaries suffer from some problems that ought to be addressed. Foremost among these problems failing to provide equivalent Arabic collocations to the English ones given, consequently committing the error of using free combinations to the English ones, hence reducing the value of this work. This is the most common problem of Ghazala's work. As for Hafiz's work, it suffers from the more serious problem of being of scanty and limited range in covering Arabic collocations.

The process of collocation presentation in the two dictionaries is far from being ideal. Serious effort is needed to add more material to the dictionaries by building bigger thesauri and consulting more Arabic lexicographic works and pools of data on contemporary collocations by surveying newspapers and literary works, in addition to the original Arabic thematic dictionaries and linguistic works (cf. section 1.8).

The present paper is particularly useful since it draws attention to the importance of producing perfect collocation dictionaries, much in demand by students of English/Arabic as a foreign language (EFL/AFL) and translators alike. It also draws attention to using Arabic legacy to complement deficiencies in the current collocation dictionaries. The fact that this work stresses the need to find equivalent original collocations in Arabic to the English ones is likely to foster studies in the lexical field of collocation. The study fills a gap in the literature about Arabic collocation dictionaries and invites researchers and lexicographers to make substantial contribution towards producing a more beneficial collocation dictionary. This will have ramifications pertinent to language learning in general and translation in particular. Future studies should try to furnish more proposals as to how to make Arabic collocation dictionaries more functional and practical. It is hoped that the insights presented in this study inspire researchers to do more work in the area of collocation dictionaries.

\section{References}

Abu-Ssaydeh, A. F. (1991). A Dictionary for Professional Translators. Babel, 32, 65-74.

Aisenstadt, E. (1979). Collocability Restrictions in Dictionaries. In R. K. Hartmann (Ed.), Dictionaries and Their Users (pp. 71-74). Exeter, Devon: University of Exeter.

Aitchison, J. (2003). Words in the Mind. (2nd ed.). Oxford: Blackwell.

Al-Ayoubi, Y. (2010). (Ed.). Explanation and Indexing of Fiqhu l-lughah (in Arabic). Beirut: Al-maktabatu 1-mua'asira.

Al-Iskafi, A. (1906). Mabadi'au l-lughah (in Arabic). Cairo: Dar Al-Maarif.

Allerton, D. J. (1984). Three (or Four) Levels of Word Cooccurrence Restriction. Lingua, 63, 17-39.

Alotaibi, A. (2015). The Comprehension of English Lexical Collocations by Kuwaiti Learners. International Journal of English Language and Linguistics Research, 2(3), 1-12.

Al-Thaalibi, A. (1986). Fiqhu l-lughah (in Arabic). Tripoli and Tunis: Al-Dar Al-Arabiyyah. 
Al-Yaziji, I. (1970). Nuj3atu r-raa'id wa shur3atu l-waarid fii l-mutaraadifi wa-l-mutaawarid (The Spring of the Seeker in Synonyms and Associations) (2nd ed.). Beirut: Maktabat Lubnaan.

Bahns, J. (1996). Kollokationen als lexikographisches Problem - Eine Analyse allgemeiner und spezieller Lernerwörterbücher des Englischen. Lexicographica: Series Maior, Vol. 74. Tübingen: Max Niemeyer Verlag.

Benson, M. (1985). Lexical Combinability. Papers in Linguistics, 18, 3-15.

Benson, M., Benson, E., \& Ilson, R. (1997, 2012). The BBI Dictionary of English Word Combinations. Amsterdam/Philadelphia: John Benjamins.

Brashi, A. S. (2005). Arabic Collocations: Implication for Translation. Unpublished $\mathrm{PhD}$ dissertation, University of Western Sidney.

Clear, J. (1993). Tools for the study of collocation. In M. Baker, G. Francis \& E. Tognini-Bonelli (Eds.), Text and technology: in honour of John Sinclair (pp. 271-292). Amsterdam: Benjamins.

Cowie, A. P. (1981). The treatment of collocations and idioms in learners' dictionaries. Applied Linguistics, 3, 223-235.

Emery, P. (1988). Body-part Collocations and Idioms in Arabic and English: A Contrastive Study. Unpublished $\mathrm{PhD}$, University of Manchester, Manchester.

Emery, P. (1991). Collocation in modern standard Arabic. Journal of Arabic Linguistics, 23, 56-65.

Fakhouri, S. (1995). Collocation in Interpretation from English and Arabic. Unpublished MA Thesis. Yarmouk University-Jordan.

Farghal, M., \& Obeidat, H. (1995). Collocations: a neglected variable in EFL. International review of applied linguistics in language teaching, 33(4), 315-331.

Firth, J. (1957). Modes of meaning. In J. Firth (Ed.), Papers in linguistics. Oxford: Oxford University Press.

Ghazala, H. (2007). Dar El-ilm's dictionary of collocations (English-Arabic). Beirut: Dar El-ilm.

Gries, S. (2013). 50-something years of work on collocations: What is or should be next. International Journal of Corpus Linguistics, 18(1), 137-165. http://dx.doi.org/10.1075/ijcl.18.1.09gri

Hafiz, A. (2004). Al-Hafiz Arabic Collocations Dictionary (AACD) (Arabic-English). Beirut: Libraire du Liban Publishers.

Handl, S. (2008). Essential collocations for learners of English: The role of collocational direction and weight. In F. Meunier \& S. Granger (Eds.), Phraseology in foreign language learning and teaching (Vol. 43-65). Amsterdam: John Benjamins Publishing Company.

Haywood, J. (1965). Arabic Lexicography (2nd ed.). Leiden: E. J. Brill.

Heliel, M. (1990). Collocations and Translation (in Arabic). Nouvelles de la Federation Internationale des Traducteurs - FIT Newsletter, 9, 30-50.

Hill, J., \& Lewis, M. (1997). Dictionary of Selected Collocations. London: Language.

Hussein, R. (1997). Collocations Revisited. Manuscript, Yarmouk University, Jordan.

Ibn Qutaybah, A. (1963). Adabu l-kaatib (in Arabic). Cairo: Al-Sa'adah.

Ibn Sidah, A. (1996). Al-mukhassas (in Arabic). Beirut: Dar Ihyaau T-turath.

Kjellmer, G. (1987). Aspects of English collocations. In W. Meijs (Ed.), Corpus Linguistics and Beyond (pp. 133-140). Amsterdam: Rodopi.

Leech, G. (1974). Semantics. London: Penguin.

Mahmoud, A. (2005). Collocation errors made by Arab learners of English. Asian EFL Journal. Retrieved from http://www.asian-efl-journal.com/pta_August_05_ma.php

Maurer-Stroh, P. (2004). Towards a Bilingual Adjective-Noun Collocation Dictionary of English and German. Unpublished $\mathrm{PhD}$ thesis. The University of Klagenfurt.

Moon, R. (1998). Fixed Expressions and Idioms, a Corpus-Based Approach. Oxford: Oxford University Press.

Nofal, K. (2012). Collocations in English and Arabic: A Comparative Study. English Language and Literature Studies, 2(3), 75-93. http://dx.doi.org/10.5539/ells.v2n3p75 
O'dell, F., \& McCarthy, M. (2008). English Collocations in Use Advanced. Cambridge: Cambridge University Press.

Palmer, H. E. (1933). Second interim report on English collocations. Tokyo: Kaitakusha Press.

Shamaa, N. (1978). A Linguistic Analysis of Some Problems of Arabic to English Translation. Unpublished doctoral thesis, Oxford University.

Sinclair, J. M. (1991). Corpus, Concordance, Collocation. Oxford: Oxford University Press.

Sinclair, J. M. (2004). Trust the Text. London: Routledge.

Stubbs, M. (1995). Collocations and semantic profiles: on the cause of the trouble with quantitative methods. Functions of language, 2(1), 1-33.

Svensén, B. (1993). Practical Lexicography-Principles and Methods of Dictionary-Making. Translated from the Swedish by John Sykes and Kerstin Schofield. Oxford and New York: Oxford University Press.

Trotter, W. (2000). Translation Salience: A Model of Equivalence in Translation (Arabic/English). Unpublished PhD Thesis. The University of Sydney.

Walker, C. (2009). The treatment of collocation by learners' dictionaries, collocational dictionaries and dictionaries of business English. International Journal of Lexicography, 22(3), 281-299. http://dx.doi.org/10.1093/ijl/ecp016

Wardell, D. (1991). Collocations: Teaching Word Pairs in EFL Classes. Forum, 29(2), 35-37.

Wehr, H. (1979). A Dictionary of Modern Written Arabic: Arabic-English. Wiesbaden: Harrassowitz.

Wray, A. (2002). Formulaic language and the lexicon. Cambridge: Cambridge University Press.

\section{Note}

Note 1. Alternative collocations offered for the entries FEAR, HOPE and other entries illustrated are collected from scattered parts of Al-Yaziji's Nuj3atu r-raa'id wa shur3atu l-waarid fii l-mutaraadifi wa-l-mutaawarid (The Spring of the Seeker in Synonyms and Associations) (1970). This shows it is easy to come up with real collocations from Arabic sources rather than use free combinations.

\section{Appendix A}

\section{List of the Phonemic Symbols Used in the Study}

\section{CONSONANTS}

b voiced bilabial stop

t voiceless dental stop

$\mathrm{T}$ voiceless (emphatic) dental stop

d voiced dental stop

D voiced (emphatic) dental stop

$\mathrm{k}$ voiceless velar stop

q voiceless uvular stop

? voiceless glottal stop

j voiced palatal affricate

3 voiced pharyngeal fricative

$G$ voiced velar fricative

f voiceless labio-dental fricative

$\Theta$ voiceless inter-dental fricative

d voiced inter-dental fricative

D voiced (emphatic) inter-dental fricative

$\mathrm{s}$ voiceless dental fricative 
$\mathrm{S}$ voiceless (emphatic) dental fricative

$\mathrm{z}$ voiced dental fricative

$\int$ voiceless palatal fricative

$\mathrm{x}$ voiceless uvular fricative

$\underline{h}$ voiceless pharyngeal fricative

$\mathrm{h}$ voiceless laryngeal fricative

r voiced dental trill

1 voiced lateral dental

$m$ voiced bilabial nasal

$n$ voiced dental nasal

w voiced bilabial glide

y voiced palatal glide

\section{VOWELS}

i short high front unrounded vowel

ii long high front unrounded vowel

a short central unrounded vowel

aa long low central unrounded vowel

$\mathrm{u}$ short high back rounded vowel

uu long high back rounded vowel

\section{Copyrights}

Copyright for this article is retained by the author(s), with first publication rights granted to the journal.

This is an open-access article distributed under the terms and conditions of the Creative Commons Attribution license (http://creativecommons.org/licenses/by/3.0/). 